\title{
PHARMACOGNOSY SIGNSOF AERIAL PARTS MEDICINAL PLANT ECHINOPS ALBICAULIS KAR.ET KIR
}

\author{
Kiyekbayeva LN ${ }^{1}$, Akhtaeva $\mathrm{NZ}^{2}$, Datkhayev $\mathrm{UM}^{1}$, Omarkhan $\mathrm{AB}^{2}$, Litvinenko $\mathrm{YA}^{2}$, Tynybekov $\mathrm{BM}^{2}$, Berkenov $\mathrm{AK}^{1 *}$ \\ ${ }^{1}$ Department of Pharmacy, Asfendiyarov Kazakh National Medical University, Almaty, Kazakhstan. ${ }^{2}$ Department of Organic Chemistry, \\ Al-Farabi Kazakh National University, Almaty, Republic of Kazakhstan. Email: berkenov_aidar@mail.ru
}

Received: 15 April 2015, Revised and Accepted: 22 March 2017

\section{ABSTRACT}

Objective: This work is intended to provide you with information about pharmacognosy, herbs and medicinal plants Echinops L., structured from the main issues, such as macro-morphological features of organs leaves, to the deeper and more challenging questions, pharmacognosy as the analysis of active ingredients and other substances or compounds use and healing properties.

Methods: Pieces of leaves were boiled on chloral hydrate solution - water (1:1) for 5-10 minutes to enlightenment. Then, the study objects were placed on a slide in a drop of glycerol and separated into two parts with dissecting needle. The object was covered with a cover glass. The object was viewed from both sides with the microscope. First, the object was viewed with a small $(\times 180)$, then at high $(\times 720)$, an increase by MS-300 microscope (MICROS, Austria) on the technique of microscopic and microchemical studies of medicinal plants.

Results: This manuscript is intended to provide you with information about pharmacognosy, herbs and medicinal plants Echinops L., structured from the main issues, such as macro-morphological features of organs leaves, to the deeper and more challenging questions, pharmacognosy as the analysis of active ingredients and other substances or compounds use and healing properties.

Conclusion: This work is offered as a study on the biological characteristics of medicinal plants to identify diagnostic markers and signs for the standardization of herbal medicines.

Keywords: Echinops albicaulis, Medicinal plant, Endemic, Anatomy, Morphology.

(C) 2017 The Authors. Published by Innovare Academic Sciences Pvt Ltd. This is an open access article under the CC BY license (http://creativecommons. org/licenses/by/4. 0/) DOI: http://dx.doi.org/10.22159/ajpcr.2017.v10i6.18037

\section{INTRODUCTION}

In medicine, one of the important genera is Echinops L. Genus Echinops L. is applied to Asteraceae family. Their growing area extends Eurasia and South Africa and integrates more than 120 species of Echinops plants. As Takhtadzhyan defined more than half of the species are found in the territory of the former USSR. Most of them are endemic to Central Asia and Caucasus. 58 species of genus and in Kazakhstan 18 species are found in the territory of the former USSR. Seven of them are endemics. By paleontological data from early times, Echinopsis is widespread in the Cam region and on the coast of Chu-Ily. Extracts of plants genus Echinops have antiphlogistic, fungicidal, antioxidant, and hepatoprotective activities. In the species of genus Echinops L, quinol alkaloids, sesquiterpenoids, flavonoids, triterpenes and thiophenes were determined. Drugs from Echinops plants on the peripheral damage, palayzing the facial nerve, plexitis, myopathy, asthenic state when vascular dystonia, forgetfulness, as stimulant nervous-muscle fibers under radiation are used.

One of the plant genera Echinops, which is not included in the official medicine is Echinops albicaulis - perennial and endemic. It is found in Kyzylorda Region, Betpakdala, Moyynkum, Kyzylkum (north), Aral and Balkhash. To determine its perspective for using in medicine, we need to conduct some botanical research. Through botanical research definition from diagnostic evidence in the basis of morphological and anatomical features of the plant makes it possible for further chemical studies.

The aim of research work is based on morphological and anatomical characteristics of a leaf E. albicaulis to determine diagnostic features [1-3].

\section{METHODS}

Medicinal plant E. albicaulis was collected from Malaysary gorge which is located on southwest spurs of Dzhungar Alatau in June-July, 2015.
Plant resources in this area were determined from research results of laboratory Plants bioresources from Botany and phytointroduction institute.

For the preparation of drugs dried and fixed materials of leaves were used. Pieces of leaves were boiled on chloral hydrate solution - water (1: 1) for 5-10 minutes to enlightenment. Then, the study objects were placed on a slide in a drop of glycerol and separated into two parts with dissecting needle. The object was covered with a cover glass. The object was viewed from both sides with the microscope. First, the object was viewed with a small $(\times 180)$, then at high $(\times 720)$, an increase by MS300 microscope (MICROS, Austria) on the technique of microscopic and microchemical studies of medicinal plants (Pharmacopeia of Republic Kazakhstan $1^{\text {th }}$ ed. 2008)

Cross-sections of plantleaves were prepared on microtome with freezing device OL-30 (INMEDPROM, Russia). The thickness of the anatomical sections was 10-15 microns. In particular, an anatomical study of wormwood species was carried out according to the methodological instructions of VN Vekhov with co-authors and MN Prozina [4].

\section{RESULTS AND DISCUSSION}

Medium altitude of the plant is $54.16 \mathrm{~cm}$. Medium altitude of stem is $22.7 \mathrm{~cm}$. Stem is one, short branched, densely, white-tomentose and without glandular ptosis.

Leaves are leathery. The topside of leaves has greenish-white color from loose omission. The bottom side of leaves has white color from dense, felted omission without veins. The leaves are hard and prickly (Fig. 2). These features are associated with ecological environment of plant. The leaves of the top formation are smaller than the leaves of the 
medium and lower formations. Leaf blade length of the top formation is $8.6 \mathrm{~cm}$, width is $2.9 \mathrm{~cm}$. Leaf blade length of the medium formation is $18.4 \mathrm{~cm}$, width is $6.2 \mathrm{~cm}$. Leaf blade length of the lower formation is $16.68 \mathrm{~cm}$, width is $6.75 \mathrm{~cm}$ (Fig. 1).

Medium altitude of the inflorescence is $3.14 \mathrm{~cm}$, width $3.19 \mathrm{~cm}$. Diameter of the single inflorescence is $2.07-3.42 \mathrm{~cm}$. The length of baskets is $2.62 \mathrm{~cm}$ (Fig. 3).

Cells of the upper epidermis are polygonal. Cells of parenchyma are located tightly. The type of stoma of the upper epidermis is anomocytic. In these stomata, accessory cells are absent. The guard cells are surrounded by ordinary epidermal cells. The amount of stomata on $1 \mathrm{~mm}^{2}$ area of the upper epidermis is $10.06 \pm 1.23$ (Fig. 4) [5-7]

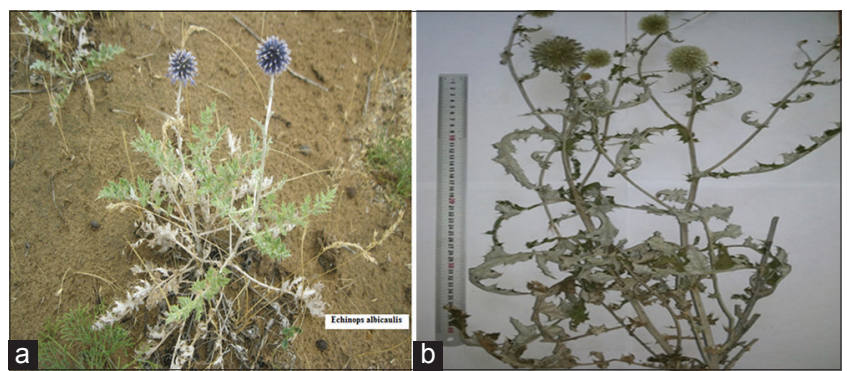

Fig. 1: (a) The locus of the plant, (b) Herbarium of plant Echinops albicaulis

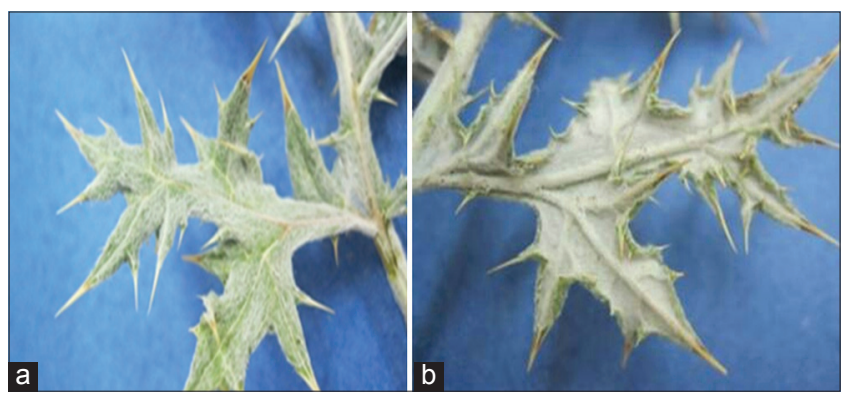

Fig. 2: (a and b) Leaves of plant Echinops albicaulis Kar et.Kir: (a) The upper epidermis, (b) the lower epidermis

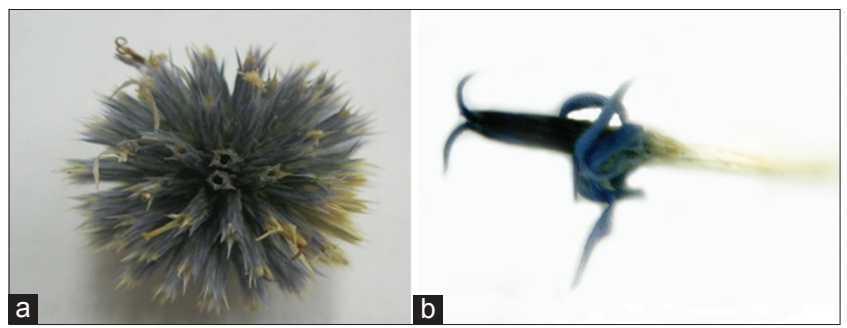

Fig. 3: (a) Inflorescence, (b) flower

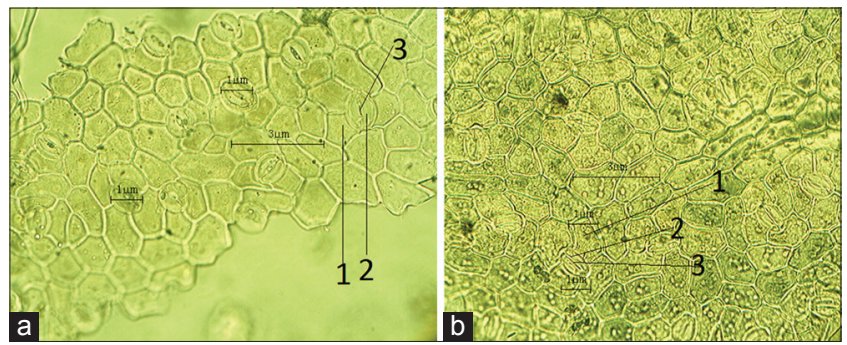

Fig. 4: The upper epidermis $\times 40$. (a and $b$ ) 1-Epidermal cells, 2 -guard cells of stoma, 3 -pore of stoma
The upper epidermis has many trichomes. Trichomes are elementary, long, celled. A lot of trichomes keep the plant insolated and perform protective function. This plant is psammofit, so it grows on sand (Fig. 5).

Compared with the upper epidermis, the lower epidermis has many trichomes. Trichomes of the lower epidermis are elementary, long, celled. The lower epidermis of the leaf is felt and white trichomes (Fig. 6).

Cells of the lower epidermis are also polygonal and located tightly. The stoma type of the lower epidermis is anomocytic. The amount of stomata on $1 \mathrm{~mm}^{2}$ area of the lower epidermis is $8.4 \pm 0.8$ (Fig. 7) [8,9].

Substances produced during the metabolism of plants are mostly stored in the form of an amorphous solid or crystals, which are called, cell compounds. On the upper and lower epidermal preparations needle-shaped crystals were found. The nature of crystals of various plants is calcium oxalate, silica, protein, and carotene. Needle-shaped crystals are in the form of rafids. Rafids are needle-shaped crystals that are connected in bunches (Fig. 8) $[4,10]$.

Chlorophyll grains participating in photosynthesis, promotes the synthesis of plant organic substance. For the synthesis of organic compounds carbon dioxide, water, and solar energy are required (Fig. 9) [11]

The upper epidermis cells of the leaf are tetragonal and thick. The lower epidermis cells of the leaf are oval and compared with the upper epidermis its size is small. Below the upper epidermis columnar mesophyll is located in two rows. The spongy mesophyll is located after columnar mesophyll. Xylem is located closer to the upper epidermis

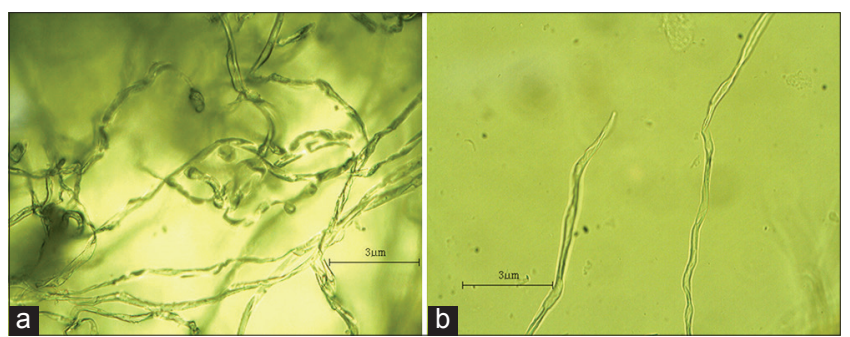

Fig. 5: (a and b) Elementary trichomes of the upper epidermis $\times 40$

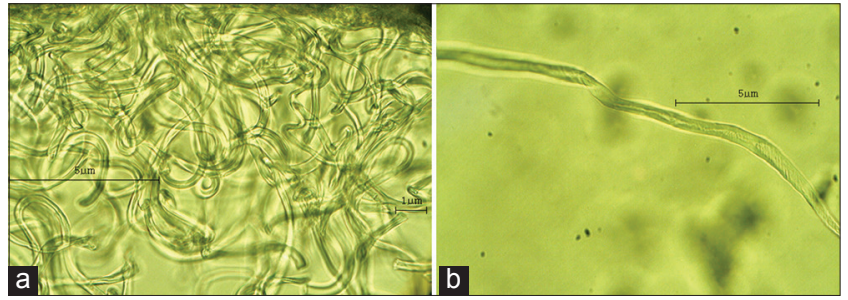

Fig. 6: $(a$ and $b)$ Trichomes of the lower epidermis $(\times 40)$

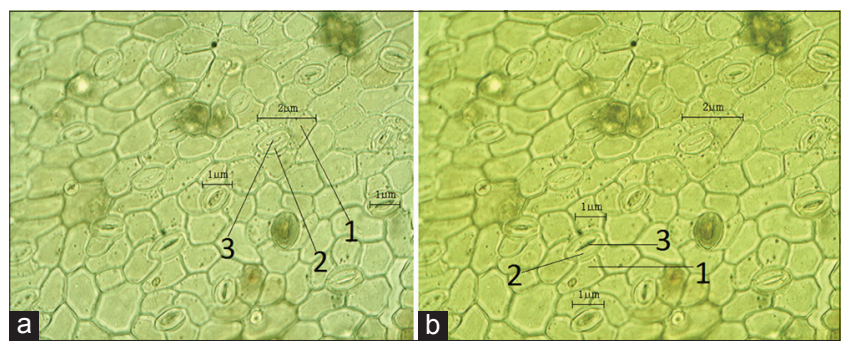

Fig. 7: (a and b) The lower epidermis $\times 40.1$ - epidermal cells, 2 quard cells of stoma, 3 - pore of stoma 
and phloem to the bottom. Hence, this is an indoor collateral ray. It is surrounded by sclerenchyma [11].

Collenchyma is located on the top and bottom of the vascular bundle. The lower epidermis of the leaf has many trichomes than the upper epidermis (Fig. 10) [12].

\section{CONCLUSION}

As a result, morphological and anatomical diagnostic features of medicinal plant $E$. albicaulis were determined. Morphological features. Medium altitude of plant is $54.16 \mathrm{~cm}$. Medium altitude of stem is $22.7 \mathrm{~cm}$. Stem is one, short branched, densely, white-tomentose, and without glandular ptosis. Leaves are leathery. The topside of the leave is greenish-white from loose omission. The bottom side of the leave is white from dense, felted omission without veins. Leaves are hard and prickly. These features are associated with ecological environment of the plant. The leaves of the top formation are smaller than the leaves of the

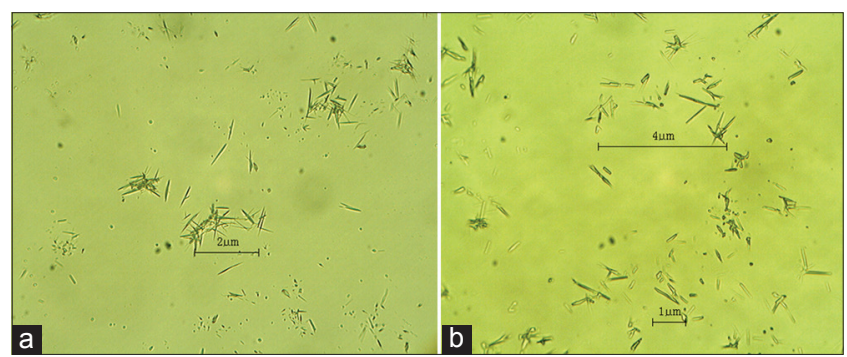

Fig. 8: ( $a$ and b) Needle-shaped crystals of the upper and lower epidermal preparations $\times 40$

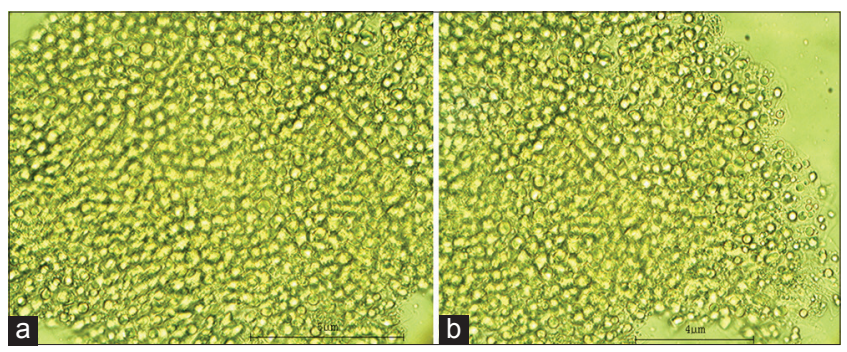

Fig. 9: ( $a$ and b) Leaf chlotophyll grains of medicinal plant Echinops albicaulis

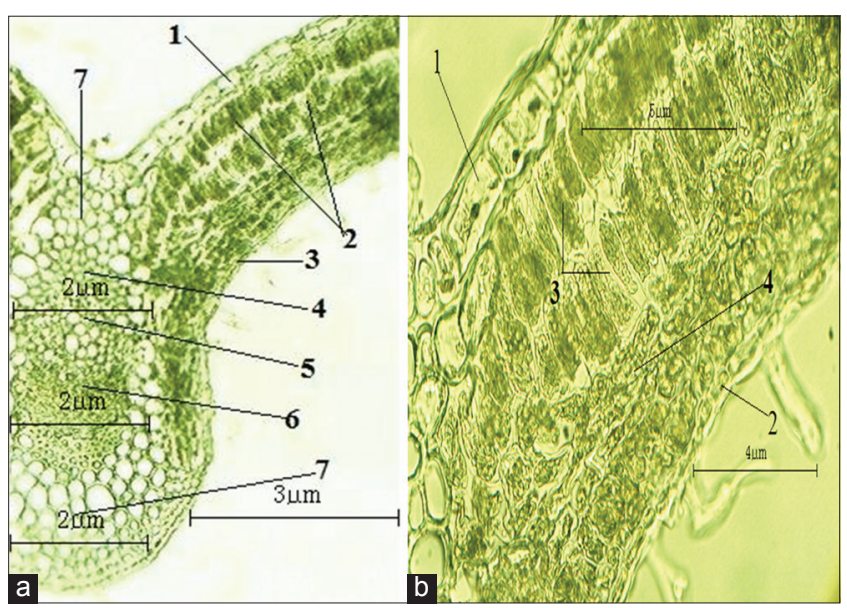

Fig. 10: Cross section of Echinops albicaulis leaf $(\times 40)$.

(a) 1 - The upper epidermis, 2 - columnar mesophyll, 3 - the lower epidermis, 4 - sclerenchyma, 5 - xylem, 6 - phloem, 7 collenchyma; (b) 1 - the upper epidermis, 2 - the lower epidermis, 3 - columnar mesophyll, 4 - spongy mesophyll medium and lower formations. Leaf blade length of the top formation is $8.6 \mathrm{~cm}$, width is $2.9 \mathrm{~cm}$. Leaf blade length of the medium formation is $18.4 \mathrm{~cm}$, width is $6.2 \mathrm{~cm}$. Leaf blade length of the lower formation is $16.68 \mathrm{~cm}$, width is $6.75 \mathrm{~cm}$. Medium altitude of inflorescence is $3.14 \mathrm{~cm}$, width is $3.19 \mathrm{~cm}$. Diameter of single inflorescence is $2.07-3.42 \mathrm{~cm}$. The length of baskets is $2.62 \mathrm{~cm}$.

Anatomical features. The upper and lower epidermis consisted of polygonal cells that are located tightly. The upper and lower epidermis have trichomes, but on the lower epidermis they are more felt and a lot. Trichomes are elementary, long, celled. The upper and lower epidermis have stomata, and they are of anomocytic type. In these stomata, accessory cells are absent. The guard cells are surrounded by ordinary epidermal cells. The amount of stomata on $1 \mathrm{~mm}^{2}$ area of the upper epidermis is $10.06 \pm 1.23$. The amount of stomata on 1 $\mathrm{mm}^{2}$ area of the lower epidermis is $8.4 \pm 0.8$. On the upper and lower epidermal preparations needle-shaped crystals were found. The nature of crystals of various plants is calcium oxalate, silica, protein, carotene. Needle-shaped crystals are in the form of rafids. Rafids are needleshaped crystals that are connected in bunches. The upper epidermis cells of the leaf are tetragonal and thick. The lower epidermis cells of leaf are oval and compared with the upper epidermis its size is small. Below the upper epidermis columnar mesophyll is located in two rows. The spongy mesophyll is located after columnar mesophyll. Xylem is located closer to the upper epidermis and phloem to the bottom. Hence, this is an indoor collateral ray. It is surrounded by sclerenchyma. Collenchyma is located on the top and bottom of the vascular bundle. The lower epidermis of the leaf has many trichomes than the upper epidermis $[13,14]$

This work is offered as a study on the biological characteristics of medicinal plants to identify diagnostic markers and signs for the standardization of herbal medicines.

\section{REFERENCES}

1. Erenler R, Yilmaz S, Aksit H, Sen O, Genc N, Elmastas M, et al. Antioxidant activities of chemical constituents isolated from Echinops orientalis Trauv. Rec Nat Prod 2014;8(1):32-4.

2. Fokialakis N, Cantrell CL, Duke SO. Antifungal activity of thiophenes from Echinops ritro. J Agric Food Chem 2006;54(5):1651-5.

3. Bankovsky AI, Perelson ME, Shevelev VA. Alkaloids Echinops. Vol. 148. Dokl USSR Academy of Sciences T; 1963. p. 1073-6.

4. Goloskokov BA. Flora of Kazakhstan. Vol. IX. Almaty, Kazakhstan: Alma-Ata, Science; 1966. p. 179.

5. Kondratieva. Methods Farmakognostics analysis: Macro And Microscopy. Vladivostok: ; 2005. p. 54.

6. Toma A, Deyno S, Fikru A, Eyado A, Beale A. In vivo antiplasmodial and toxicological effect of crude ethanol extract of Echinops kebericho traditionally used in treatment of malaria in Ethiopia. Malar J 2015;14:196.

7. Toroglu S, Keskin D, Vural C, Kertmen M. Menderes Cenet. Comparison of antimicrobial activity of Echinops viscosus Subsp. Bithynicus and E. Microcephalus leaves and flowers extracts from turkey. Int J Agric Biol 2012;14:85-94

8. Tulegenova AO. National Pharmacopeia of Republic Kazakhstan. V. II. 2008. p. 685-743.

9. Vekhov VN, Lotova LI, Phylin VR. Workshop on the Anatomy and Morphology of Higher Plants. Moscow, Moscow State University Publishing House; 1980. p. 196.

10. Zharylgasina GT, Shults EE, Turmuhambetov AZ, Adekenov SM. Component composition of Echinops subglaber SHRENK. And Echinops meyeri (DC.) ILJIN, Scientific and practical journal. Pharm Pharmacol Pyatigorsk 2014;6(7):15.

11. Sviridonov G.M. Young Guard. Moscow: Spring of Health-Moscow; 1986. p. 223

12. Gemedzhieva NG. The biological activity of alkaloid containing plants in Kazakhstan, Almaty. Biol Med Ser 2010;1(277):24-30.

13. Kudaibergenova MK, Hakimzhanova J, Kiekbaeva L, Akhtaeva NZ, Mamurova AT, Datkhayev UM, et al. Phytochemicals study of plant Echinops albicaulis, Almaty 2015;1:6-9.

14. Kiyekbayeva L, Mohamed NM, Yerkebulan O, Mohamed EI, Ubaidilla D, Nursulu A, et al. Phytochemical constituents and antioxidant activity of Echinops albicaulis. Nat Prod Res 2017;1:1-5. 